\title{
Teacher-Student Relationship is Enhanced by the Gratitude of Teacher Perspective in Religious Based Elementary School
}

\author{
$1^{\text {st }}$ E. H. Ansyah \\ Student of Doctoral Psychology of \\ Psychology Faculty, Universitas \\ Airlangga \\ Surabaya, Indonesia \\ Psychology Department, Faculty of \\ Psychology and Educational Science \\ Universitas Muhammadiyah Sidoarjo \\ ekohardiansyah@umsida.ac.id
}

\author{
$2^{\text {nd }} C$. Hadi \\ Psychology Department, Faculty of \\ Psychology \\ Universitas Airlangga, Surabaya, \\ Indonesia
}

\author{
$3^{\text {rd }}$ N. A. F. Nawangsari \\ Psychology Department, Faculty of \\ Psychology \\ Universitas Airlangga, Surabaya, \\ Indonesia
}

\begin{abstract}
The teacher student relationship problem is more increasing. Therefore it is necessary to find evidence about how gratitude correlates with teacher student relationship. This study aimed to find out whether there is a relationship between teacher gratitude and the teacherstudent relationship at religion based elementary school. This research was conducted with correlation research design. The participants of this research consist of 65 teachers from a religion based elementary school. The research measurements used two scales, namely the teacher student relationship scale (TSRS) from Pianta and the teachers gratitude scale (TGS) from Watkin. The scales were given to participants then analyzed. The results showed that there is a relationship between gratitude and the teacher student relationship. It also indicated that the low teacher student relationship of the participants could be enhanced by improving the gratitude. The implication of this research implementation are discussed.
\end{abstract}

Keywords-teacher's gratitude, teacher student relationship, elementary school, teacher development, character education

\section{INTRODUCTION}

The Research on teacher and student relations has long been used and has become a study in educational psychology related to instructional, interpersonal, and relational processes [1]. Unfortunately, the low quality of teacher and student relationship in Indonesia lately become a serious problem that needs attention [2]. Various cases that occur between the teacher and students were the proof. Some national news entitled 'Teachers beat students, persecute teachers against students, students at the teacher's slap' became evidence of a teacher-student relationship problem that cannot be underestimated [3]. Research on teacher-student relations is an effort that needs to be done because it has significant impacts on the development of teachers and students. Student teacher relationship proved to have impacts on the development of all students in school [4], [5]. The importance of teacher-student relationship is also evidenced that the existence of a positive relationship between the teacher and students will bring motivation [6], quality, and success in school for the students themselves [7] as well as reading achievement and mathematics [8].

Not only for students, high teacher-student relations also have impacts on teachers. The high teacher-student relationship forms positive well-being and teacher selfefficacy [9], [10]. Researches on teacher-student relationship have shown that internal and external factors can influence the strength of student teacher relationship. Internal factors such are genetic factors, namely dopaminergic gene, gender and race [11], [12]. Another factors are person's psychological factors which related to self-determination, teacher's gratitude, and individual externalization behavior [9], [13], [14]. In addition, it was found that the teacher's temperament is also able to influence teacher-student relationship [15].

However, the past research about teacher's gratitude and teacher student relationship is conducted in the middle school context, not in the elementary school context. Whereas previous studies have proven that gratitude has a correlation with one's social competence, such as prosocial behavior, and motivation to contribute to society [16], [17]. Therefore, the purpose of this study is to prove whether teachers' gratitude has an influence on teacher student relationship according to teachers perspective in elementary school based religion or not. Another thing that distinguishes between this research and previous research is that this study takes context in elementary schools with Islamic religion-based education as written by Olufadi [18] who stated that Islamic rituals that are built in Muslim individuals are able to build positive relations with others. 
The hypothesis developed in this study is that there is a relationship between teachers' gratitude and teacher relations of students according to the teacher's perspective in Islamic-based elementary schools.

\section{METHODS}

This research describes in detail using a quantitative correlational approach that aims to determine the extent to which variations in one variable are related to variations in one or more other variables. Participants in this study were all teachers who taught at a religion-based school in Sidoarjo. The total number of participants was 65 teachers with an average age of 41 years. The measurement in this study uses two instruments, the first is the teacher-student relationship scale (TSRS-Indonesian version) $(\alpha=0.949)$. This scale was adapted from teacher-student relationship scale (TSRS) from Pianta [19], [20] which was translated to Indonesian context. TSRS-Indonesian version is used as an instrument to reveal teacher student relationship variable. This scale was developed using three indicators, namely closeness, conflict, and dependence. the second instrument was Teacher's Gratitude Scale (TGS) $(\alpha=$ 0.873 ), whereas to measure teacher's gratitude variable. The TGS adapted from Watkins [21] which was developed using three indicators, namely a sense of appreciation, positive feelings for life, and a tendency to act positively. The hypothesis proposed in this study is that there is a correlation between teacher's gratitude and teacher student relationship according to the teacher's perspective in religion-based elementary schools.

\section{RESULTS AND DISCUSSION}

Data analysis was performed using Pearson's product moment correlation analysis because the distribution of data discharged the assumption that it was normally distributed. The results of data analysis show the following results:

TABLE I. DESCRIPTIVE STATISTICS

\begin{tabular}{|c|c|c|c|}
\hline & Mean & Std. Deviation & N \\
\hline Gratitude & 46.0923 & 6.22174 & 65 \\
\hline Teacher student relationship & 58.7846 & 6.57764 & 65 \\
\hline
\end{tabular}

TABLE II. CORRELATIONS

\begin{tabular}{|c|c|c|c|}
\hline \multirow{3}{*}{ Gratitude } & Gratitude & $\begin{array}{c}\text { Teacher student } \\
\text { relationship }\end{array}$ \\
\cline { 2 - 4 } & Pearson Correlation & 1 & $.340^{* *}$ \\
\cline { 2 - 4 } & Sig. (2-tailed) & & .006 \\
\hline Relationhip & N & 65 & 65 \\
\cline { 2 - 4 } & Pearson Correlation & $.340^{* *}$ & 1 \\
\cline { 2 - 4 } & Sig. (2-tailed) & .006 & 65 \\
\hline
\end{tabular}

Based on the results of data analysis in table II, it can be seen that the hypothesis is accepted rxy $=0.340 ; \rho=0.006$; $\rho>0.05$ which shows that there is a relationship between

TABLE III. PERCENTAGE OF PARTICIPANT CATEGORIES

\begin{tabular}{|c|c|c|c|c|}
\hline \multirow{2}{*}{ Categories } & \multicolumn{4}{|c|}{ Participants score for each variable } \\
\cline { 2 - 5 } & \multicolumn{3}{|c|}{ Gratitude } & Teacher student Relationship \\
\cline { 2 - 5 } & $\sum$ & $\%$ & $\sum$ & $\%$ \\
\hline Very low & 3 & $5 \%$ & 5 & $7 \%$ \\
\hline Low & 22 & $33 \%$ & 17 & $26 \%$ \\
\hline Average & 27 & $41 \%$ & 12 & $18 \%$ \\
\hline High & 5 & $7 \%$ & 22 & $33 \%$ \\
\hline Very high & 8 & $12 \%$ & 9 & $13 \%$ \\
\hline & 65 & & 65 & \\
\hline
\end{tabular}

TABLE IV. PERCENTAGE OF TEACHER STUDENT RELATIONSHIP LOW LEVEL INDICATORS

\begin{tabular}{|c|c|c|}
\hline Indicators & Amount of participants & Percentage \\
\hline Closeness & 25 & $39 \%$ \\
\hline Conflict & 14 & $21 \%$ \\
\hline Dependence & 11 & $17 \%$ \\
\hline
\end{tabular}

The results of this study prove that teacher gratitude is able to improve the quality of teacher-student relationship teacher's gratitude and the teacher student relationship with a positive and significant relationship. 
gratitude will help them to feel a greater connection with their students. Where teachers become more proactive to get to know their students and teachers become more able to build rapport. This result is also supported by table 3 data where teachers who have very high gratitude (12\%) are also followed by the teacher student relationship who are also very high $(13 \%)$.

Gratitude is a moral influence that can encourage someone to take prosocial actions that are not only felt by the beneficiaries but also the gratitude giver, and able to build children's motivation to contribute to society [16], [17], [22]. This study provides a good contribution that by expressing gratitude, the teacher will become a person who can give closeness to their students so that the teacher student relationship becomes stronger.

Thus, gratitude has a significant influence on teacher student relationship. However, the percentage data of the participants of this study (see table 3 ) displayed that there were still many participants who shown low gratitude quality and teacher student relations. Which are $38 \%$ of participants had low and very low gatitude levels and $33 \%$ showed low or very low teacher student relationship. This can be a problem in the school since the quality of teacher relations students have a significant influence on elementary school students' academic achievement [23]. Thus, in the future, researchers hope there are strategic steps taken by elementary schools principles to improve teacher-student relationship. Moreover, the school in this study is based on religion. Whereas religious approaches such as psychology of al-Fatihah, stated it can help to improve the happiness of teachers and students which can also lead to student learning achievement [24].

According to table 4, the lowest level of teacher student relationship based on the indicators indicate that the most difficulties of teachers to strengten relationship is on this indicator. These are characterized by the teacher feel that their student are not open, and teacher cannot to be the role model for the student. It are also the teacher perception that they cannot make their student happy, cannot support their students, and teacher also cannot give comfort feeling to their student. From these characteristics, we could be focusing the improvement of teacher student relationship by the gratitude from their closeness to the student.

The implication of this study is to provide support for the Character Education Strengthening program (PPKIndonesian term) in elementary schools. Concentration of character education in the implementation of Indonesian national education is considered as the heart of national education because it needs to be continued, optimized, deepened, and expanded so that a national character education program is strengthened [25]. The presence of gratitude by the teacher is believed to have a significant impact on the PPK program.

Limitation of this research is that this study only reaches the population in Muhammadiyah Elementary School, but does not cover a higher level of junior high school or high school. Therefore the same research should be conducted to get an overview related to the development of the concept of teacher student relationship starting from providing support for the idea that children develop unique work models related to their social world based on their initial experience in dealing with adults who care for them. From here, forming early development and influencing children's school experiences then it was concluded that early relations with adults play an important role in the formation of social competencies which are often translated by positive adjustments.

\section{CONCLUSION}

This study showed that teacher's gratitude has a significant impact on teacher student relationship, especially on teachers in elementary schools with educational based religion. Thus, it is expected that teachers in this elementary school will further enhance the ability to express their gratitude towards fellow teachers and students so that the quality of teacher student relationship can be greater. With strong teacher student relationship, students' learning achievements are also believed to increase. To realize this, the school principles are expected to take the initiative to implement the teachers' gratitude enhancement program and integrate this teacher's gratitude into a program to strengthen character education in elementary schools.

\section{ACKNOWLEDGMENT}

We would say thank you to Universitas Muhammadiyah Sidoarjo for the support of this research financially. The budget is used to fund the conference cost and publishment.

\section{REFERENCES}

[1] W. M. Reynolds and G. E. Miller, "Current perspectives in educational psychology," in Handbook of psychology: Educational psychology, New Jersey: John Wiley \& Sons, Inc., 2003, pp. 3-20.

[2] E. H. Ansyah, C. Hadi, and S. Handoyo, "Teacher-student relationship and its urgencies in Indonesia: A literature review," in Advances in Social Science, Education and Humanities Research (ASSEHR), 2018, vol. 125, no. 1st International Conference on Intellectuals' Global Responsibility (ICIGR 2017), pp. 108-112.

[3] Liputan6.com, "Kumpulan kekerasan guru terbaru hari Ini," liputan6.com, 2017. [Online]. Available: http://www.liputan6.com/tag/kekerasan-guru. [Accessed: 30-Jul2017]

[4] S. H. Birch and G. W. Ladd, "The teacher-child relationship and children's early school adjustment," J. Sch. Psychol., vol. 35, no. 1, pp. 61-79, 1997.

[5] R. C. Pianta, B. Hamre, and M. Stuhlman, "Relationship between teachers and children," in Handbook of Psychology: Educational Psychology, vol. 7, W. M. Reynolds and G. E. Miller, Eds. New Jersey: John Wiley \& Sons, Inc., 2003, pp. 199-234.

[6] K. R. Wentzel, "Social relationships and motivation in middle school: The role of parents, teachers, and peers.," J. Educ. Psychol., vol. 90, no. 2, pp. 202-209, 1998.

[7] B. K. Hamre and R. C. Pianta, "Early teacher-child relationships and the trajectory of children's school outcomes through eighth grade.," Child Dev., vol. 72, no. 2, pp. 625-638, 2001.

[8] M. P. Mccormick, E. E. O'Connor, and E. P. Horn, "Can teacherchild relationships alter the effects of early socioeconomic status on achievement in middle childhood?," J. Sch. Psychol., vol. 64, no. May, pp. 76-92, 2017.

[9] M. Zee and H. M. Y. Koomen, "Similarities and dissimilarities between teachers' and students' relationship views in upper elementary school: The role of personal teacher and student attributes," J. Sch. Psychol., vol. 64, no. May, pp. 43-60, 2017.

[10] L. Claessens et al., "Beginning and experienced secondary school teachers' self- and student schema in positive and problematic teacher-student relationships," Teach. Teach. Educ., vol. 55, pp. 88-99, 2016. 
[11] S. De Laet et al., "Teacher-student relationships and adolescent behavioral engagement and rule-breaking behavior: The moderating role of dopaminergic genes," J. Sch. Psychol., vol. 56, pp. 13-25, 2016.

[12] E. M. Jerome, B. K. Hamre, R. C. Pianta, and O. I. Way, "Teacher-child relationships from kindergarten to sixth grade: Early childhood predictors of teacher-perceived conflict and closeness," Sos. Dev., vol. 18, no. 4, pp. 915-945, 2014.

[13] T. Jungert, B. Piroddi, and R. Thornberg, "Early adolescents' motivations to defend victims in school bullying and their perceptions of student-teacher relationships: A selfdetermination theory approach," J. Adolesc., vol. 53, pp. 75-90, 2016.

[14] K. Howells, "An exploration of the role of gratitude in enhancing teacher-student relationships," Teach. Teach. Educ., vol. 42, pp. 58-67, 2014.

[15] M. Oren and I. Jones, "The Relationships between child temperament, teacher-child relationships, and teacher-child interactions," Int. Educ. Stud., vol. 2, no. 4, pp. 122-133, 2009.

[16] J. J. Froh, G. Bono, and R. Emmons, "Being grateful is beyond good manners: Gratitude and motivation to contribute to society among early adolescents," Motiv. Emot., vol. 34, no. 2, pp. 144$157,2010$.

[17] A. M. Grant and F. Gino, "A Little Thanks Goes a Long Way : Explaining Why Gratitude Expressions Motivate Prosocial Behavior Communal Mechanism: Social Worth," J. Pers. Soc.
Psychol., vol. 98, no. 6, pp. 946-955, 2010.

[18] Y. Olufadi, "Muslim Daily Religiosity Assessment Scale (MUDRAS): A new instrument for Muslim religiosity research and practice," Psycholog. Relig. Spiritual., vol. 9, no. 2, pp. 165179, 2017.

[19] R. C. Pianta, "Measures developed by Robert C. Pianta, Ph.D.," University of Virginia. 2012.

[20] R. C. Pianta, The student teacher relationship Scale. Charlottesvilee: University of Virginia, 1992.

[21] P. C. Watkins, K. Woodward, T. Stone, and R. L. Kolts, "Gratitude and happiness: Development of a measure of gratitude, and relationship with subjective well being," Soc. Behav. Pers., vol. 31, no. 5, pp. 431-452, 2003.

[22] M. E. McCullough, R. A. Emmons, and J.-A. Tsang, "The grateful disposition: A conceptual and empirical topography," $J$. Pers. Soc. Psychol., vol. 82, no. 1, pp. 112-127, 2002.

[23] D. B. Hajovsky, B. A. Mason, and L. A. Mccune, "Teacherstudent relationship quality and academic achievement in elementary school: A longitudinal examination of gender," $J$. Sch. Psychol., vol. 63, no. September 2016, pp. 119-133, 2017.

[24] E. H. Ansyah and C. Hadi, "Psikologi al-fatihah: Solusi untuk mencapai kebahagiaan yang sebenarnya," J. Psikol. Islam, vol. 4, no. 2, pp. 107-120, 2017.

[25] Kemdikbud RI, Konsep dan pedoman Penguatan Pendidikan Karakter: Tingkat sekolah dasar dan sekolah menengah pertama. Jakarta: Kementrian Pendidikan Nasional, 2017. 